\title{
Türkiye'de Kamu Personeli Alanında Hazırlanan Lisansüstü Tezlerin İçerik Analizi: 1986-2018
}

\author{
Content Analysis of Graduate Thesis Prepared By Staff in Public Personnel in Turkey: 1986-2018
}

\section{Murşit IŞIK}

Dr. Ögr. Üyesi, Süleyman Demirel Üniversitesi, İ̈BF

Çalı̧̧ma Ekonomisi ve Endüstri İlişkiler Bölümü,

mursitisik@sdu.edu.tr

https://orcid.org/0000-0001-9855-6290
Makale Başvuru Tarihi: 20.08.2019

Makale Kabul Tarihi: 03.09.2019

Makale Türü: Araştırma Makalesi
Keywords:

Public Personnel,

Public

Administration,

Graduate Thesis,

\begin{abstract}
Anahtar
Kelimeler:

Kamu Personeli,

Kamu Yönetimi,

Lisansüstü Tez,

Türkiye'de kamu personeli olgusu, iş arayan kişilerin kamu personeli olabilmek için girdiği sinavlarla, kamu personeline verilen ücretlerle, kamu personelinin atanmast ve zaman zaman kamu hizmetlerinin aksamasl ve rüsvet gibi konularla toplumun gündeminden hiç düsmeyen bir konu olma özelliğini sürdürmektedir. Akademik olarak ta kamu personeli, kamu çalışanı, devlet memuru gibi kavramlar adı altında araştırmalar yapılmakta, kamu personelinin sorunları tespit edilip çözüm önerileri sunulmaya çalışılmaktadır. Araştırma lisansüstü düzeyde kamu personeli kavramı kullanılarak yapılan çalışmaların nitel olarak incelenmesini amaçlamıștır. Bu kapsamda 1986-2018 yılları arasında hazırlanan 52 adet tez, tezlerin türü, temel konusu, dili, yapıldığ değişkenlerle gruplandırllarak analiz edilmeye çalışılmıştır.
\end{abstract}

\section{ÖZET}

\section{ABSTRACT}

The fact of public employees in Turkey is a popular subject that never falls off the agenda of the society with some specific matters such as the occupational exams to become a public personnel, the wages given to public personnel, the appointment of public personnel, the disruption of public services from time to time and bribery.In academic terms, researches have been carried out under the titles of public personnel, public employees, civil servants, problems of public personnel and after the problems are identified the required solutions are proposed. This study aims to examine qualitatively the studies carried out using the concept of public personnel at graduate level. In this context, 52 theses prepared between the years 1986-2018 were analyzed by grouping them with variables such as type of thesis, main subject, language, university, institute, department, access to theses and methods applied to theses. 


\section{GIRISS}

Başta devlet olmak üzere tüm kamu kurum ve idareleri tarafından hukuki normlar ile öngörülen kamu hizmetlerinin yerine getirilebilmesi için malvarlığı ve uygulayıcılara (personele) ihtiyaç duyulmaktadır. Bu bağlamda kamu personeli, kamu hizmetlerinin etkin, verimli ve yasal olarak yürütülmesi, devlet tüzel kişiliğinin fonksiyonlarının yerine getirilmesi açısından önemli olan çalışanlardır. Kamu personeli çeşitli sorunlarıyla sürekli gündemde olan personeldir. Bu sorunlar yapılan birçok araştırmada dile getirilmiş, zaman zaman siyasi iktidarlar tarafından çözümlenmeye çalışılmış, ancak bir türlü gerekli tüm çözümler ortaya konulamamıştır.

Kamu personelinin ücreti uzun yıllardır süregelen bir sorundur. Piyasa koşullarında yeterli ücreti alamamaktan, eşit işe eşit ücret verilmemesinden, personel arasındaki (memur-işçi) farklılıklardan, bordroların yeterince anlaşılır olmamasından kadar bir çok sorun ücretle ilişkilendirilmiştir.

Kamu personelinin atanmasında liyakat ilkesine yeterince riayet edilmemesi, kariyer sisteminin yeterince uygulanamaması, performans sistemine bir türlü tam anlamıyla geçilememesi ve devletin halen en büyük işveren yada kamu sektörünün hala istihdamın gözdesi olan bir sektör olarak görülmesi sayılabilecek sounların başında gelmektedir.

$\mathrm{Bu}$ araştırmada kamu personeli hakkında yapılan tezlerin değişik açılardan sınıflandırılması yapılarak akademik camiada hangi konuların sorun olarak görüldüğü ve daha çok hangi konular üzerine yoğunlaşıldığı konusunda bir çıkarımda bulunmak amaçlanmıştır.

\section{KAMU PERSONELİ KAVRAMI VE KAMU PERSONELININ SORUNLARI}

Personel kelimesi Fransızca "Personnel" kelimesinden Türkçeye girmiş olup, bir hizmet yada kuruluşun görevlileri, bir işyerinde çalışanlar veya bir etkinliğe çeşitli görevleriyle katılan gerçek kişilerdir (Tdk, 2011:www.tdk.gov.tr). Personel, birden fazla kişiyi anlatan çoğul bir sözcüktür (Güler, 2005:10). Kamu personeli ise kamusal faaliyetlerin ve hizmetlerin yürütülmesinde çalıştırılan, görev alan insan gücüdür (Örnek, 1998:198).

Literatürde kamusal faaliyetleri ve hizmetleri yürütenler, kamu görevlisi, kamu çalışanı, devlet görevlisi, bürokrat, memur, kamu emekçisi, kamu personeli gibi farklı kavramlarla ifade edilmektedir. Personel Hukukuna ilişkin mevzuatta "memurlar ve diğer kamu görevlileri" ifadesi kullanılmaktadır. Memur dişındaki diğer kamu görevlileri ise yargıçlar, akademisyenler, askerler gibi kendi özel yasaları bulunanlar ile kamuda sözleşmeli olarak çalışanlardır (Bozkurt vd., 1998:127-128).

Kamu Görevlisi bir kamu kurumunda personel olarak çalışanlarla (memur, işçi, sözleşmeli) kamu otoritesini kullanan kişileri (bakan, belediye başkanı, il genel meclisi üyeleri, vb.) kapsayan geniş bir kavram olmasına karşın, kamu personeli ise seçimle değil atamayla göreve gelen kişileri kapsayan bir kavramdır (Güler, 2005:62).

Tablo 1. Kamu Görevlisi Türleri

\begin{tabular}{|l|l|}
\hline Kamu Görevlisi Türü & Kapsama Giren Kamu Görevlileri \\
\hline En genişanlamda & $\begin{array}{l}\text {-Seçimle ve atama ile gelenler } \\
\text {-işçiler } \\
\text { (Merkez ve taşra, yerel yönetimler } \\
\text { ve kamu kurumlarında çalışanlar) }\end{array}$ \\
\hline Geniş anlamda & $\begin{array}{l}\text {-Seçimle ve atama ile gelenler } \\
\text { (Yürütme üyeleri, yerel } \\
\text { yönetimlerin seçimle veya atama } \\
\text { ile gelen görevlileri) }\end{array}$ \\
\hline Dar anlamda & $\begin{array}{l}\text {-Memurlar ve sözleşmeli personel } \\
\text { (meslek olarak kamu görevlisi) }\end{array}$ \\
\hline En dar anlamda & -Devlet memurları \\
\hline
\end{tabular}

Kaynak: Gözler, 2009:623-625; Kayar, 2011:39-44; Mecek ve Doğan, 2015:212-213.

Tablo 1 de de ifade edildiği gibi, kamu görevlisi en geniş anlamda seçimle, atamayla gelenler ve işçileri de kapsamakta iken, geniş anlamda işçiler hariç seçimle ve atamayla gelenleri, dar anlamda memur ve sözleşmeli personeli, en dar anlamda da sadece memurları kapsayan bir kavramdır. Bu anlamda kamu personeli seçilmişler dışında, memurlar, sözleşmeliler ve işçileri kapsayan bir kavram olarak karşımıza çıkmaktadır. 
Tablo 2. Kamu Personeli Sayısal Verileri

A) KAMU PERSONELININ STATÜLERINE VE ISTIHDAM EDILDIKLERI KURUM TÜRLERINE GÖRE DAĞILIMI(*) (ARALIK 2018)

\begin{tabular}{|c|c|c|c|c|c|}
\hline \multicolumn{2}{|c|}{ ISTIHDAM TŨR0 } & $\begin{array}{l}\text { BAKANUIKLAR BAĞLI, } \\
\text { ILGILI VE iLISSKGILI } \\
\text { KURULUȘLAR }\end{array}$ & $\begin{array}{l}\text { KIT'LER VE KAMU } \\
\text { SERMAYELI } \\
\text { KURULUȘLAR }\end{array}$ & MAHALLI IDARELER & GENEL TOPLAM \\
\hline \multicolumn{2}{|l|}{ MEMURLAR(“") } & 2.307 .746 & 4.156 & 110.350 & 2.422 .252 \\
\hline \multicolumn{2}{|c|}{ HAKIM VE SAVCILAR } & 19.383 & & & 19.383 \\
\hline \multicolumn{2}{|c|}{ ÖGRETIM ELEMANLARI } & 132.671 & & & 132.671 \\
\hline \multirow{2}{*}{$\begin{array}{l}\text { SÖZLESMMELI } \\
\text { PERSONEL("“") }\end{array}$} & 657 /4B KAPSAMINDA SŐZZEȘMELI PERSONEL & 107.890 & \multirow{2}{*}{70.091} & \multirow{2}{*}{15.547} & \multirow{2}{*}{254.563} \\
\hline & DIGGER SÖZLEȘMELI PERSONEL & 61.035 & & & \\
\hline \multirow{4}{*}{ işÇiLER } & SÜREKLi ișçiLER & 442.449 & 45.062 & 83.160 & \multirow{4}{*}{658.527} \\
\hline & GEÇici ișçilLER & 11.952 & 9.675 & 4.340 & \\
\hline & KAPSAM DIȘI IŞÇILER & & 3.279 & & \\
\hline & KAMU BANKALARINDAKI IŞÇILER( $\left.{ }^{\prime \cdots * *}\right)$ & & 58.610 & & \\
\hline \multicolumn{2}{|l|}{ TOPLAM } & 3.083 .126 & 190.873 & 213.397 & 3.487 .396 \\
\hline \multicolumn{5}{|c|}{ GENEL TOPLAM } & 3.487.396 \\
\hline
\end{tabular}

Kaynak: DPB, 2018:http://www.dpb.gov.tr/tr-tr/istatistikler/kamu-personeli-istatistikleri.

Tablo 2'de 2018/Aralık dönemi itibariyle bakanlıklar ile bakanlıklara bağlı, ilgili ve ilişkili kuruluşlarda 3.083.126 personel, KİT'ler ve kamu sermayeli kuruluşlarda 190.873 personel, mahalli idarelerde ise 213.397 personel olmak üzere toplamda 3.487.396 kişi istihdam edilmektedir.

Türkiye'de kamu personelinin birçok sorunu bulunmaktadır. Bu sorunlar Devlet Personel Başkanlığı tarafindan 26-27 Ocak 2013 tarihinde Kamu Personel Sisteminin Sorunları ve Çözüm Önerileri ve 2023 Vizyonu Çalıştay'ında 9 başlık halinde ele alınmıştır. Bu sorunlar şunlardır (DPT, 2013:http://www.dpb.gov.tr/);

- 666 sayılı KHK'nın maaş eşitsizliğine yol açması,

- Memurların öğrenim durumuna uygun kadro derecesine yükseltilmemesi,

- Dengesiz personel dağılımı,

- Memur ve işçi olmak üzere iki statünün belirlenmesi, hizmet sınıflarının gözden geçirilmesi,

- Kamu görevlilerine grev hakkı verilmemesi,

- Ticaret ve siyaset yasaklarının kaldırılmaması,

- İşçi ve memurlar arasındaki maaş ve ikramiye farklarının giderilmemesi,

- Memur maaş sistemi yeniden düzenlenmesi,

- Aynı ildeki refakatçilere izin verilmesi, yıllık izinlerde iş günü esası getirilmesi.

Kamu hizmetlerinin etkili ve verimli bir şekilde yürütülebilmesi kamu personel sisteminin iyi işlemesine ve görevlerini tam anlamıyla yerine getiren liyakatli personelin varlı̆̆ına bağlıdır. Kamu hizmetlerinin başarı ve başarısızlığ personel sistemine ve personele bağlıdır. O halde sorunların temel kaynağını, personel sistemi ve personel olmak üzere ikiye ayrımak mümkündür. Sistemden kaynaklanan sorunlar birbiriyle bağlantılı sorunlardır. Bu sorunlar şu şekilde belirtilebilir (Yıldırım, 2016:18);

- Liyakat ilkesinin iyi işlememesi,

- Kariyer sisteminin uygulanamamas1,

- Ücret dengesinin kurulamamış olması,

- Bilimsel bir sınıflandırmanın yapılamamış olması,

- Personel değerlemesinde nesnel ölçütlerin geliştirilememiş olmasıdır. 
Türk kamu personel sisteminde personelden kaynaklanan sorunlar şu şekilde sıralanabilir (Yıldırım, 2016:34);

- İletişim sorunu (personelin birbirleriyle iletişime geçerken sorun yaşamaları),

- Değişime kapalılık (personelin modern yönetim sisteminin getirmiş olduğu yenilikleri kabul etmeme ve uygulama yeterliliğine sahip olmamaları),

- Sorumluluktan kaçma (yöneticilerin vermiş olduğu görevleri kabul etmeme veya verilen görevleri yerine getirmeme, yapılan işleri yarım bırakmaları),

- Katılım eksikliği (yapılan etkinliklere katılmama, düşüncesini belli etmeme gibi davranış özellikleri personelden kaynaklanan sorunlar olarak karşımıza çıkmaktadır).

\section{YÖNTEM}

\subsection{Araştırmanın Amacı ve Kapsamı}

Türkiye'de kamu personeli konusunda yapılan lisansüstü tezleri incelemek amaciyla yapılan bu araştırma kapsamında; tezlerin türü, temel konusu, dili, yapıldığı üniversite, enstitü, anabilim dalı, tezlere erişim durumu, tezlere uygulanan yöntemler gruplandırılmıştır. Bu verilere, YÖK tez veri tabanından "kamu personeli" anahtar kelimesi ile tarama yapılarak ulaşılmıştır. 2019 yılı temmuz ayı itibariyle 52 adet tez çalışma kapsamında incelenmiş olup, araştırmanın evrenini Türkiye'de kamu personeli üzerine yapılan lisansüstü tezler oluşturmaktadır. Örneklemini ise ulaşılabilen 52 adet tez oluşturmaktadır.

Araştırmada nitel araştırma yöntemlerinden doküman incelemesi tekniği kullanılmıştır. Nitel araştırmayı, "gözlem, görüşme ve doküman analizi gibi nitel veri toplama tekniklerinin kullanıldığı, alglların ve olayların doğal ortamda gerçekçi ve bütüncül bir biçimde ortaya konmasına yönelik nitel bir sürecin izlendiği araştırma" olarak tanımlamak mümkündür (Yıldırım ve Şimşek, 2008:39).

\subsection{Araştırmanın Sınırlııkları}

Kamu personeli alanında yapılan araştırma kapsamında, yükseköğretim kurulu tez veri tabanından ulaşılan bazı tezlerin tam metnine erişimin sınırlı olması sebebiyle bu tezlerin tez künyelerinden özetleri incelenmiştir. Ayrıca "kamu çalışanları" "kamu görevlileri" "devlet memuru" anahtar kelimeleri de kamu personeli kavramı içine girmesine rağmen bu araştırmada kamu personeli dışındaki diğer kavramlar başlığında hazırlanan tezler inceleme kapsamı dışında tutulmuştur.

\section{BULGULAR}

Çalışmanın bu kısmında YÖK Ulusal Tez Merkezi'nde bulunan lisansüstü tezler incelenerek değişik açılardan sınıflandırılmaya çalışılmış tablo, şekil ve grafikler araştırmacı tarafından hazırlanmıştır.

Şekil 1. Kamu Personeli Alanında Yazılan Tezlerin Düzeyi

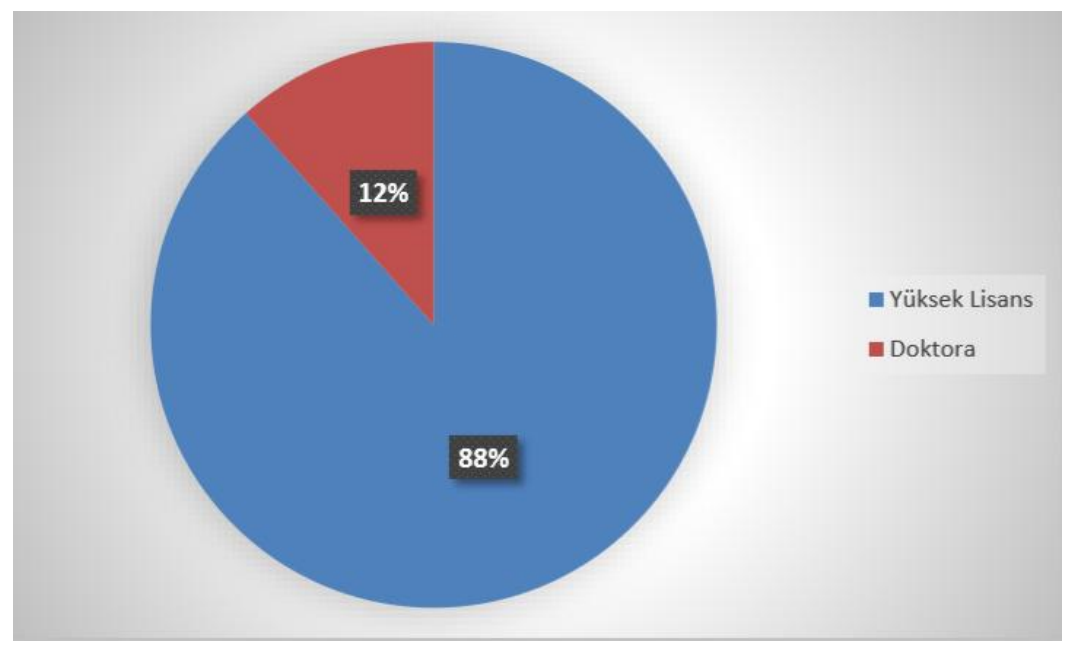

Kaynak: Yazar tarafından hazırlanmıştır. 
Şekil l'de görüldüğü üzere kamu personeli hakkında yapılan tezlerin 46 tanesi (\%88) Yüksek lisans, 6 tanesi de (\%12) doktora düzeyinde olduğu tespit edilmiştir.

Şekil 2. Kamu Personeli Alanında Yazılan Tezlerin Yazım Dili

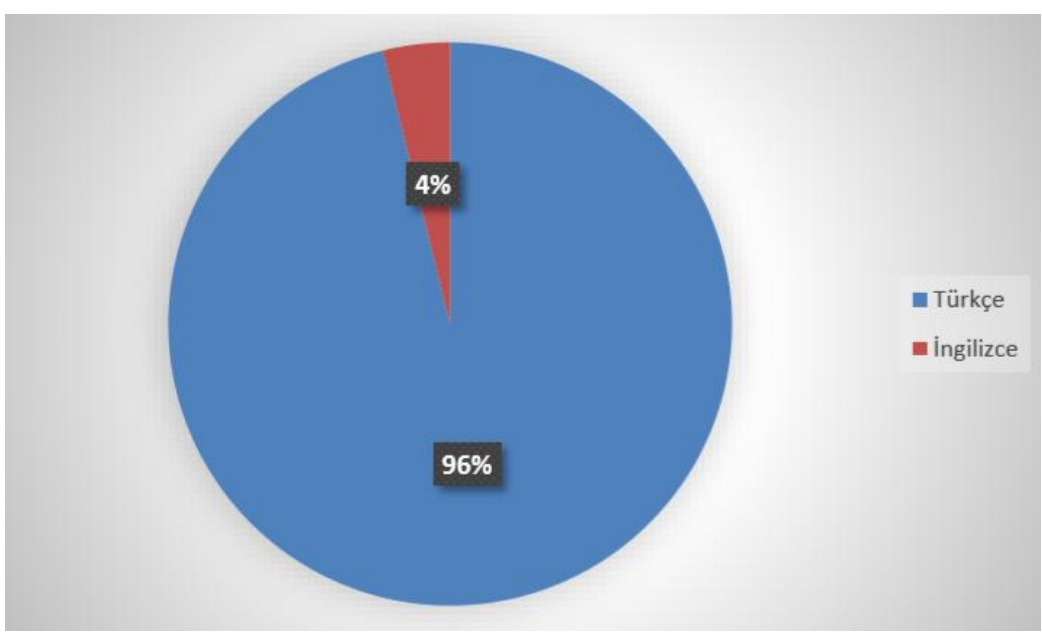

Kaynak: Yazar tarafindan hazırlanmıştır.

Şekil 2'den anlaşılacağı üzere kamu personeli hakkında yapılan tezlerin 50 tanesinin (\%96) Türkçe, 2 tanesinin de (\%4) İngilizce olarak hazırlandığg görülmektedir.

Grafik 1. Kamu Personeli Alanında Yazılan Tezlerin Enstitü Dağılımları

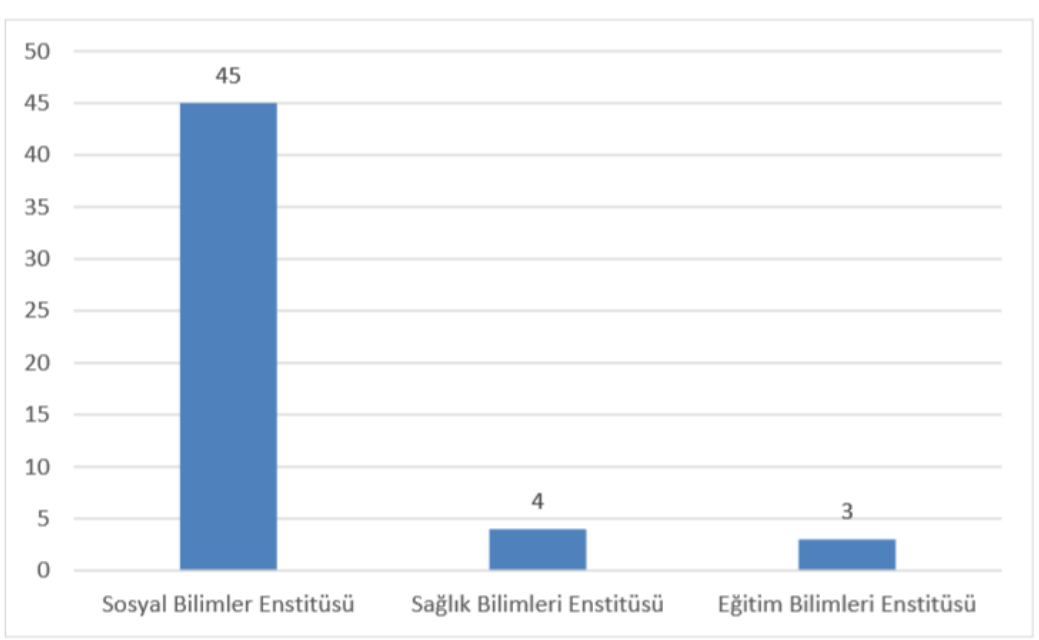

Kaynak: Yazar tarafından hazırlanmıştır.

Grafik 1'de görüldüğü üzere kamu personeli hakkında yapılan tezlerin (45) adedi Sosyal Bilimler Enstitüsü, (4) adedi Sağlık Bilimleri Enstitüsü, (3) adedi de Eğitim Bilimleri Enstitüsü bünyesinde hazırlanmıştır. 
Grafik 2. Kamu Personeli Alanında Yazılan Tezlerin Yıllara Göre Dağılımı

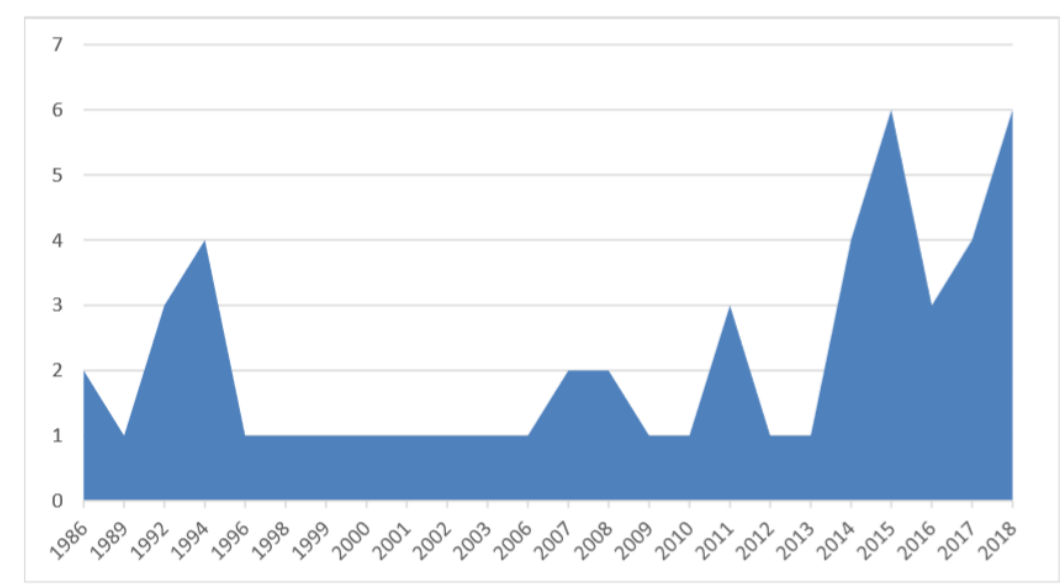

Kaynak: Yazar tarafından hazırlanmıştır.

Grafik 2'de görüldüğü üzere kamu personeli hakkında 2018 ve 2015 yıllarında (6 ) adet; 2017, 2014 ve 1994 yıllarında (4) adet; 2016, 2011 ve 1992 yıllarında (3) adet; 2008, 2007 ve 1986 yılarında (2) adet; diğer yıllarda ise (1) adet tez hazırlanmıştır.

Grafik 3. Kamu Personeli Alanında Yazılan Tezlerin Ait Olduğu Üniversiteler

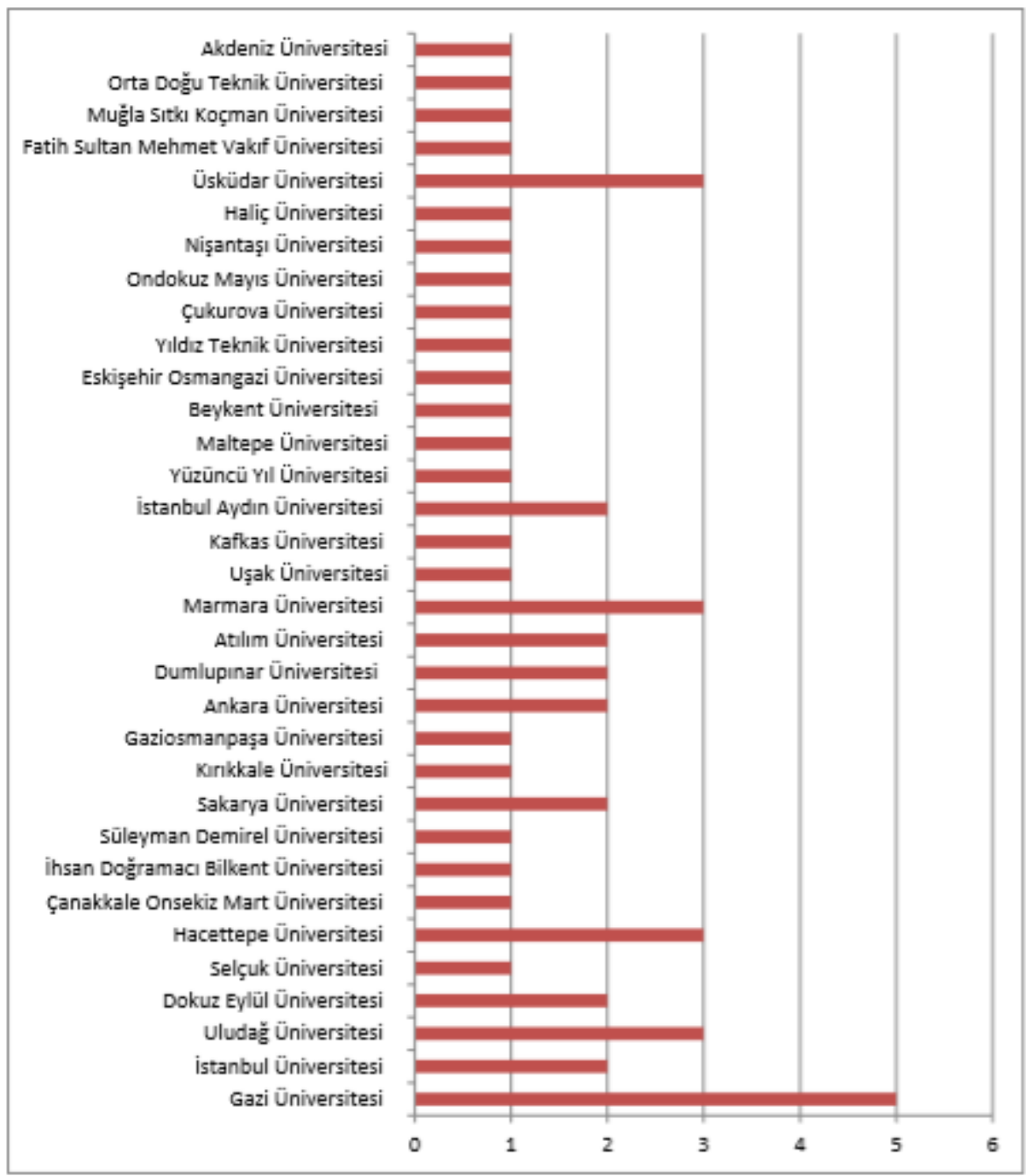

Kaynak: Yazar tarafından hazırlanmıştır. 
Grafik 3 'te görüldüğü üzere kamu personeli hakkında en fazla tez Gazi Üniversitesi (5) öğrencileri tarafından hazırlanmıştır. Sonrasında ise (3)'er tezle Uludağ Üniversitesi, Hacettepe Üniversitesi, Marmara Üniversitesi ve Üsküdar Üniversitesi öğrencilerinin takip ettiği tespit edilmiştir.

Grafik 4. Kamu Personeli Alanında Yazılan Tezlerin Ait Olduğu Anabilim Dalları

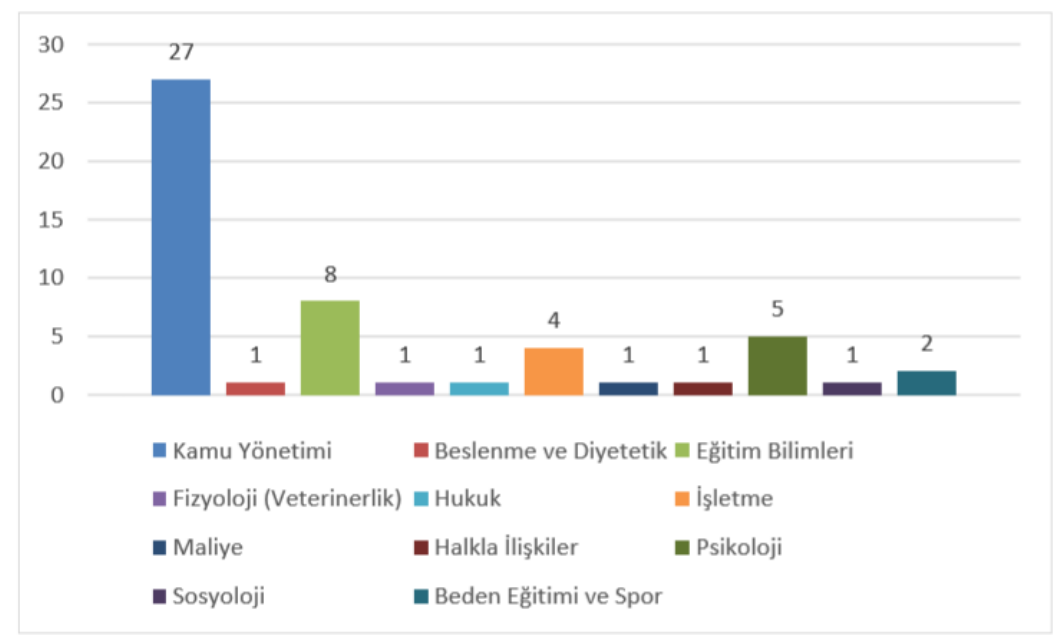

Kaynak: Yazar tarafından hazırlanmıştır.

Grafik 4'te görüldügü üzere kamu personeli hakkında yazılan tezlerin 27 adedi Kamu Yönetimi, 8 adedi Eğitim Bilimleri, 5 adedi Psikoloji, 4 adedi İşletme, 2 adedi Maliye Ana Bilim Dalında, geriye kalanlar (1'er adet) ise Beslenme ve Diyetetik, Fizyoloji (Veterinerlik), Hukuk, Maliye, Halkla İlişkiler ve Sosyoloji Ana Bilim Dallarında hazırlanmıştır.

Şekil 3. Kamu Personeli Alanında Yazılan Tezlerde Uygulanan Yöntemler

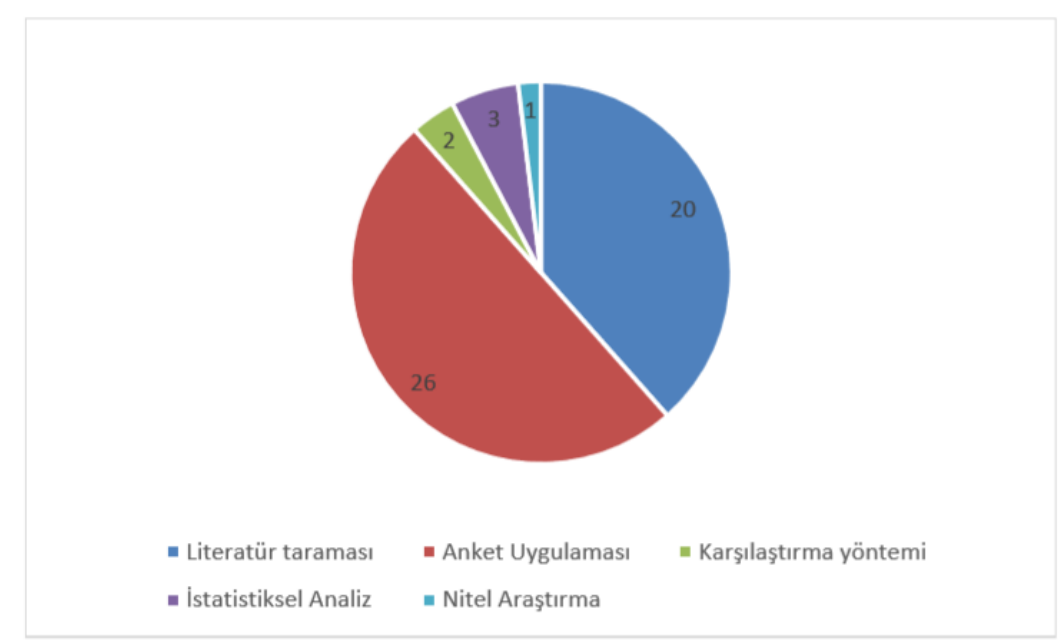

Kaynak: Yazar tarafindan hazırlanmıştır.

Şekil 3'te görüldüğü üzere kamu personeli hakkında yazılan tezlerin 26 adedinde anket, 20 adedinde literatür taraması, 3 adedinde istatistiksel analiz, 2 adedinde karşılaştırma, 1 adedinde ise nitel araştırma yöntemi kullanılmıştır. 
Grafik 5. Kamu Personeli Alanında Yazılan Tezlerin Temel Konuları

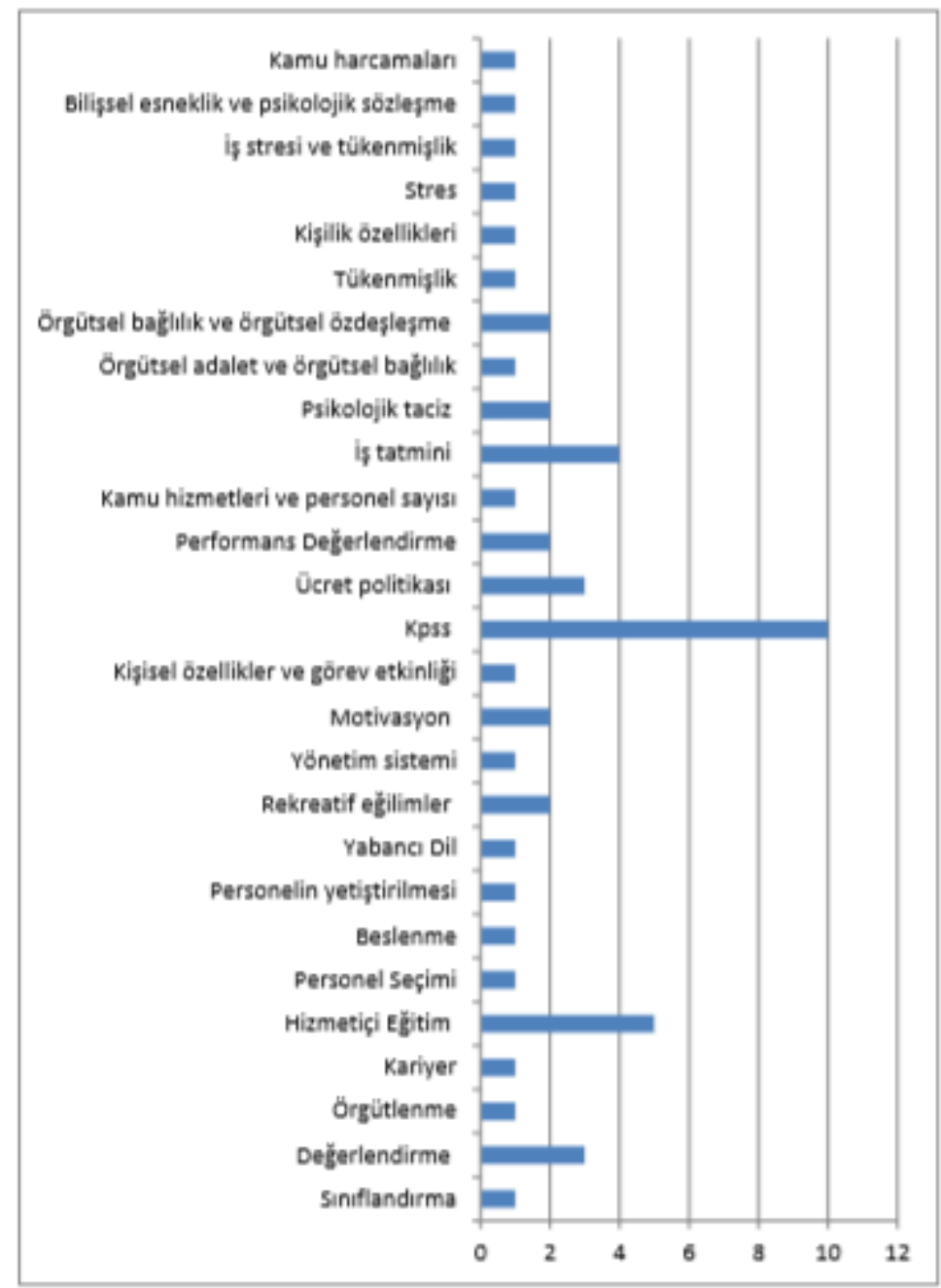

Kaynak: Yazar tarafından hazırlanmıştır.

Grafik 5 'te görüldüğü üzere kamu personeli alanında hazırlanan tezlerin temel konularından 10 adedi KPSS, 5 adedi hizmet içi eğitim, 4 adedi iş tatmini, 3 adedi değerlendirme ve ücret politikası, 2'şer adedi ise rekreatif eğilimler, motivasyon, performans değerleme, psikolojik taciz, örgütsel bağl1lik ve örgütsel özdeşleşme konularında hazırlanmıştır. Genel olarak bakıldığında tezlerin 19 adedinin yönetim psikolojisi ve çalışma psikolojisi alanlarında hazırlandığı söylenebilir.

Şekil 4. Kamu Personeli Alanında Yazılan Tezlerin Erişim Durumu

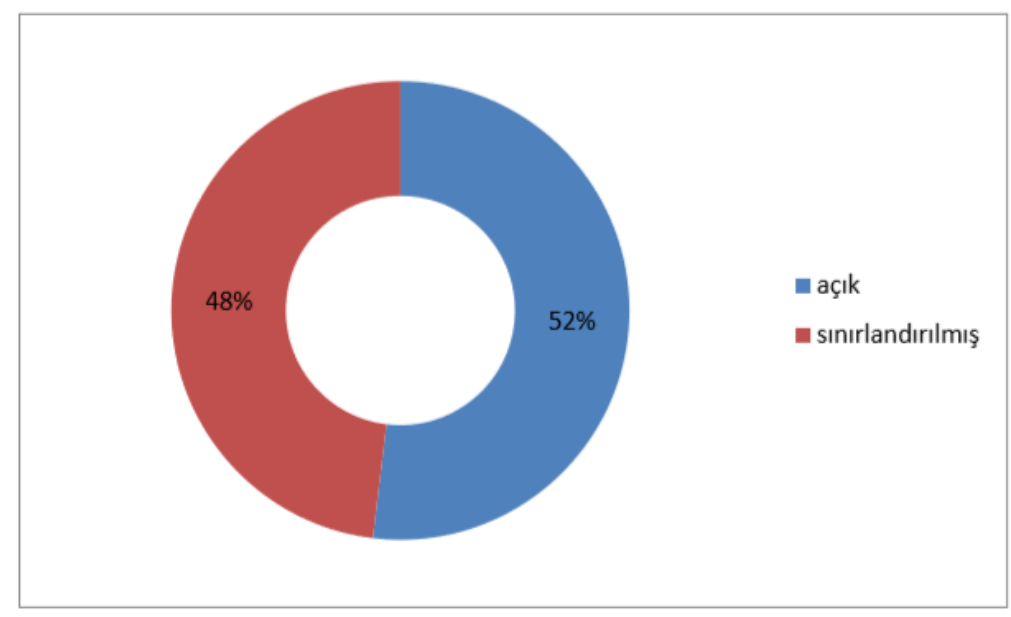

Kaynak: Yazar tarafindan hazırlanmıştır. 
Şekil 4'te görüldüğü üzere kamu personeli konusunda hazırlanmış tezlerin 27 adedi (\%52) erişime açık iken, 25 adedinin (\%48) erişimi sınırlandırılmıştır.

\section{SONUC}

Kamu personeli konusunda yapılan araştırmalar incelendiğinde Doktora düzeyinde $\% 12$ oranla yeterince çalışmanın olmadığı, hazırlanan tezlerin \%96'sının Türkçe olarak yazıldığı, \%86'sının Sosyal Bilimler Enstitüsü bünyesinde hazırlandığı, 2015 yılından sonra bu alanda yapılan tez sayısında artış gözlendiği. Hazırlanan tezlerin büyük çoğunluğunun devlet üniversiteleri bünyesinde yapıldığı, anabilim dalı olarak \%52'sinin Kamu Yönetimi Ana Bilim Dalında hazırlandığı, \%50'sinde anket yönteminin kullanıldığı, tezlerin temel konularına bakıldığında ise KPSS konusunun en fazla ele alınan konu olduğu, ama genel anlamda ise yönetim psikolojisi ve çalışma psikolojisi alanlarına giren konuların daha çok incelendiği ve tezlerin $\% 52$ 'sinin erişime açık olduğu görülmüştür. Bu sonuçlardan anlaşılacağı üzere Türkiye'de kamu personeli olabilmek yada kamu sektöründe istihdam imkanı bulabilmek için geçilen süreçlerden biri olan KPSS sınavları önemli bir sorun olarak görülmekte, ayrıca tezlerin temel konularının genel olarak yönetim psikolojisi alanında olması kamu personelinin psikolojik durumunun ortaya konulması açısından önemlidir.

Türkiye'de akademik çevre kamu personelinin sorunlarına daha kapsamlı ve daha detaylı bir şekilde eğilmeli Doktora düzeyindeki tez çalışmaları arttırılmalı, yabancı ülkelerde uygulanan sistemler ile Türk Kamu Personel Sistemini karşılaştıran araştırmaların sayısı arttırılmalı, Üniversitelerle kamu kurum ve kuruluşları bu konuda işbirliği yaparak araştırmaların il düzeyinde kalmaması tüm Türkiye düzeyinde yapılması için kolaylık sağlamalıdır.

\section{KAYNAKLAR}

BOZKURT, Ömer, ERGUN, Turgay ve SEZEN, Seriye (1998), Kamu Yönetimi Sözlüğü, TODAİE Yayını, Ankara.

DPB - DEVLET PERSONEL BAŞKANLIĞI (2013), "Kamu Personel Sisteminin Sorunları ve Çözüm Önerileri ve 2023 Vizyonu Çalıştayı", E-Haber (Kurumsal Web Sayfası), http://www.dpb.gov.tr/tr-tr/haber/kamupersonel-sisteminin-sorunlar\%C4\%B1-cozum-onerileri-ve-2023-vizyonu-cal\%C4\%B1stay\%C4\%B1-270 (Erişim Tarihi: 15.08.2019).

DPB - DEVLET PERSONEL BAŞKANLIĞI (2018), Kamu Personeli İstatistikleri, Devlet Personel Başkanlığ Yayını, Ankara, http://www.dpb.gov.tr/tr-tr/istatistikler/kamu-personeli-istatistikleri (Erişim Tarihi:15.08.2019).

GÖZLER, Kemal (2009), İdare Hukuku, Ekin Kitabevi, Bursa, 2.Bask1, Cilt:2.

GÜLER, Birgül Ayman (2005), Kamu Personeli: Sistem ve Yönetim, İmge Kitabevi Yayınları, Ankara.

KAYAR, Nihat (2011), Kamu Personel Yönetimi, Ekin Yayınları, Bursa, 3.Bask1.

MECEK, Mehmet ve DOĞAN, Hüsna (2015), "İstihdam Açısından Yerel Yönetimlerin Organizasyon Yapısı ve Personel Yönetimi", İdari ve Mali Açıdan Türkiye'de Yerel Yönetimler (Ed. Mehmet Mecek, Mesut Doğan, Bekir Parlak), Bekad Yayınları, Antalya, ss.209-272.

ÖRNEK, Acar (1998), Kamu Yönetimi, Meram Yayın Dağıtım, İstanbul.

TDK - TÜRK DİL KURUMU (2011), "Personel", Güncel Türkçe Sözlük, Türk Dil Kurumu Yayını, Ankara, 11.Bask1, www.sozluk.gov.tr (Erişim Tarihi: 15.08.2019).

YILDIRIM, Cuma (2016), "Türk Kamu Personelinin Kişilik Özellikleri Üzerine Bir Araştırma: Samsun Il Yönetimi Örneği", Yayınlanmamış Yüksek Lisans Tezi, Samsun Ondokuz Mayıs Üniversitesi Sosyal Bilimler Enstitüsü, Samsun. 